\title{
Ismertetés: Élelmiszer, egészség és komplexitás: egy olyan koncepcionális megértés felé, amely az együttmúködésen alapuló népegészségügyi cselekvést irányítja
}

\author{
Food, health, and complexity: towards a conceptual understanding to \\ guide collaborative public health action
}

Ismerteti: $\quad$ Erdei Gergő $\square$

Országos Gyógyszerészeti és Élelmezés-egészségügyi Intézet

Szerzők: Shannon E. Majowicz, Samantha B. Meyer, Sharon I. Kirkpatrick, Julianne L. Graham, Arshi Shaikh, Susan J. Elliott, Leia M. Minaker, Steffanie Scott, Brian Laird

Megjelenés: BMC Public Health

DOI: https://doi.org/10.1186/s12889-016-3142-6

Beküldve: 2017.10.26.

doi: 10.24365/ef.v58i4.198

Kulcsszavak: Népegészségügy, közösségi beavatkozás, népesség alapú tervezés, élelmiszerallergia, elhízás

Keywords: Public health, Public policy, population-based planning, food allergy, obesity

\section{ÖSSZEFOGLALÁS}

A cikk célja egy modell kidolgozása, amely bemutatja a lehetséges kölcsönhatásokat az élelmiszerfertőzés, élelmiszerbiztonság, étrendi kontamináció, elhízás és élelmiszerallergia között. A 49 vizsgált tényező közül 14 mutat közvetlen kapcsolatot az étrendi kontaminációval, 14 az élelmiszer allergiával, 15 az élelmiszerfertőzéssel, 33 az élelmiszerbiztonsággal, 39 az elhízással. Az elhízás és az élelmiszerbiztonság osztotta meg a legtöbb tényezőt
( $n=28)$. Az elhízás és az élelmiszer allergia $(n=11)$, élelmiszerfertőzés $(n=7)$, étrendi kontamináció ( $n=6)$ között szintén találtak közös tényezőket. Az élelmiszerbiztonság és az élelmiszerfertőzés ( $n=9)$ és az étrendi kontamináció ( $n=9)$ között is van közös kapcsolat. További közös kapcsolat volt még az élelmiszerfertőzés és az étrendi kontamináció $(n=8)$ között. Néhány tényező közös volt az élelmiszerallergia esetében az élelmiszerbiztonsággal $(n=4)$, élelmiszerfertőzéssel $(n=2)$ és az étrendi kontaminációval is.

\section{TANULSÁGOK A SZAKEMBEREK SZÁMÁRA}

A cikkben részletezett népegészségügyi problémák között bonyolult kapcsolat figyelhető meg, amely arra utal, hogy a beavatkozások tervezésénél figyelembe kell venni, hogy ezek egymással kölcsönhatásba léphetnek, és váratlan következményekkel járhatnak. 
1. ábra: 14 tényezö, amely az 5 élelmiszerekkel kapcsolatos népegészségügyi problémák közül legalább 3-mal összefügg

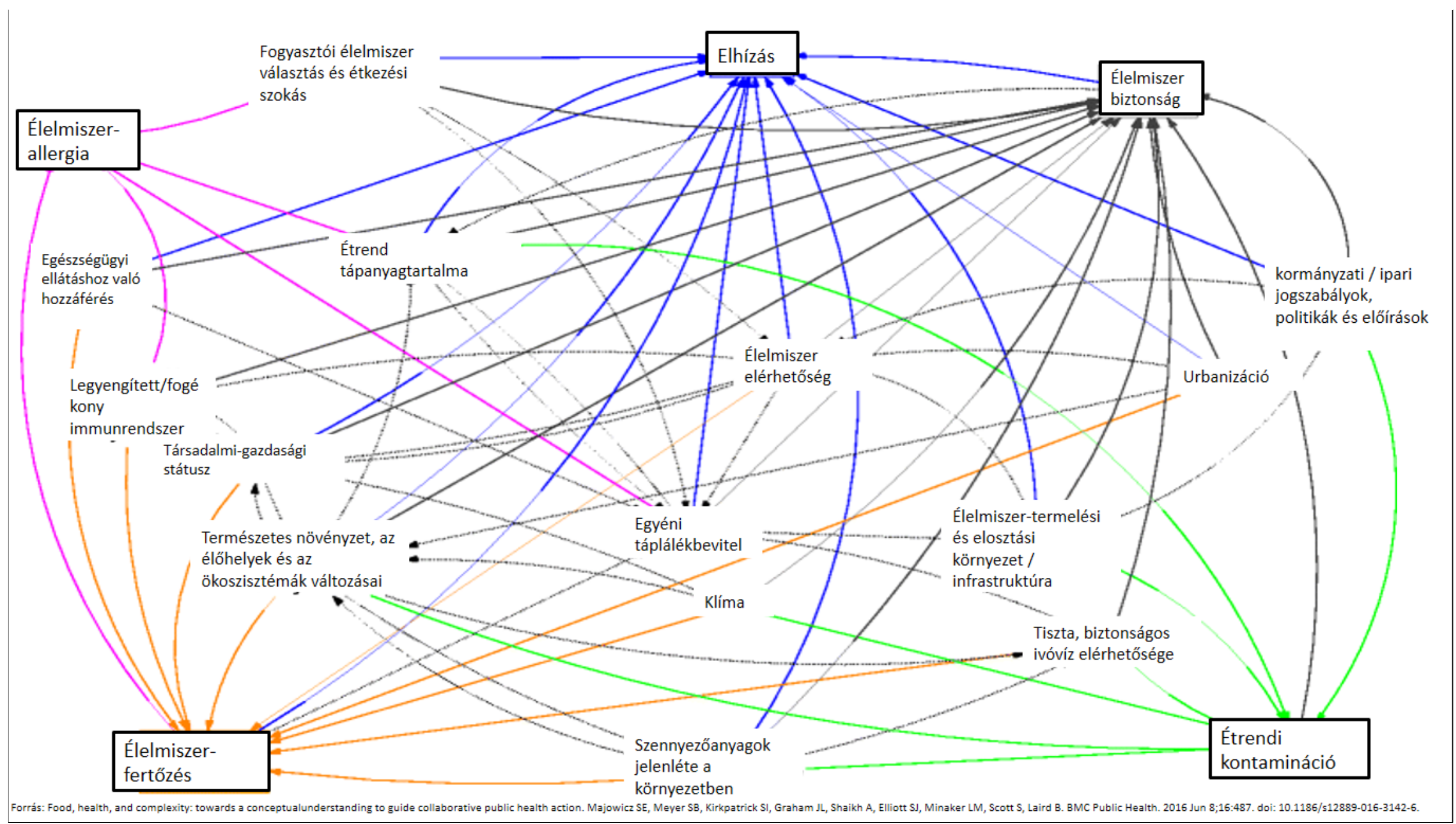

